\title{
Root growth plasticity to drought in seedlings of perennial grasses
}

\author{
Hans Martin Hanslin (D) - Armin Bischoff • \\ Knut Anders Hovstad
}

\begin{abstract}
Aim Root growth strategies may be critical for seeding survival and establishment under dry conditions, but these strategies and their plasticity are little known. We aim to document the ability of young grass seedlings to adjust their root system architecture, root morphology and biomass allocation to roots to promote water uptake and survival under progressive drought.

Methods Seedlings growing in columns filled with sand and exposed to drought or well-watered controls were repeatedly harvested for determination of biomass fractions, root length, -architecture and -morphology in a greenhouse experiment. Allometric scaling exponents
\end{abstract}

Responsible Editor: Zhun Mao.

Electronic supplementary material The online version of this article (https://doi.org/10.1007/s11104-019-04117-7) contains supplementary material, which is available to authorized users.

H. M. Hanslin $(\bowtie)$

Department of Urban Greening and Environmental Engineering, The Norwegian Institute of Bioeconomy Research (NIBIO), Postbox 115, 1431 Ås, Norway

e-mail: hans.martin.hanslin@nibio.no

\section{A. Bischoff}

Mediterranean Institute of Biodiversity and Ecology, IMBE, Aix-Marseille University, Avignon University, CNRS, IRD, IUT Agroparc, BP 61207, 84911 Avignon Cedex 9, France

K. A. Hovstad

Department of Landscape and Biodiversity, The Norwegian Institute of Bioeconomy Research (NIBIO), Postbox 115, 1431 Ås, Norway and standardised major axis regression were used to investigate allocation patterns.

Results Young seedlings were able to sustain leaf turgor and functions during eight weeks of progressive drought through phenotypic plasticity of the primary root system producing deeper and simpler roots. Biomass allocation to roots decreased or did not respond, and other components of root morphology showed only moderate plasticity.

Conclusion Our results suggest that morphological and architectural plasticity of the primary root system may well be key features for dehydration avoidance and survival in grass seedlings under moderate drought when allocation of biomass to roots and development of secondary roots are constrained.

Keywords Allometry · Seedling strategies · Rooting depth $\cdot$ Root system architecture

\section{Introduction}

Seedling survival is critical for plant establishment, but is severely constrained by both biotic and abiotic factors (Moles and Westoby 2004; James et al. 2012). Water availability is one of these critical factors for seedling performance in many systems, typically where seasonal droughts are common (Lloret et al. 2005; Padilla and Pugnaire 2007; Gaviria and Engelbrecht 2015). Hence, drought may impose a high selection pressure on seedlings (Moles and Leishman 2008), driving adaptations in root growth strategies to acquire water. As the soil is a 
complex heterogeneous matrix, plastic root traits involving morphology, physiology and allocation patterns are fundamental to the growth of functional root systems (Fitter 2002; Forde 2009). Nevertheless, less plastic root growth strategies are often observed in species adapted to drier conditions (Nicotra et al. 2002; Padilla and Pugnaire 2007) and studies have found a negative relationship between drought tolerance and root plasticity (e.g. Couso and Fernández 2012) indicating trade-offs along humidity gradients. Insight into root growth strategies will improve the understanding of seedling recruitment and regeneration niches and their impacts on resilience, succession and community assembly under current and future climate. This information will also be valuable in applied fields such as restoration ecology where seedling mortality can be a major constraint for restoration success. In remote areas, such as alpine sites and dryland areas, construction work often leave behind a highly disturbed soil profile that restrict root development. Under such conditions, root growth strategies are expected to be important for seedling survival during dry periods and in turn, seedling recruitment and establishment. Knowledge of these relationships can be used for sourcing of plant material for ecological restoration.

Species of mesic and hydric habitats show a high degree of root plasticity, with dynamic biomass allocation to capture nutrients in patches or water both in shallow and deeper soil layers (e.g. Hodge 2004; Hodge et al. 2009; Padilla et al. 2009; RamírezValiente et al. 2019). Traits for tissue morphology, architecture and physiology may be even more plastic than biomass allocation (Comas et al. 2013). Plastic responses to water availability have been observed for physiological traits such as abscisic acid and proline content (Davies and Bacon 2003) and morphological traits and phene aggregates such as specific root length (Padilla et al. 2009, 2013), rooting depth (Reader et al. 1993; Alvarez-Flores et al. 2014), root length (Bell and Sultan 1999), root:shoot ratios (Padilla et al. 2009) and root surface area (Saidi et al. 2010). The adaptive value of trait plasticity for seedling performance under drought is, however, highly dependent on the intensity and duration of drought episodes and interactions with other environmental conditions (Tardieu 2012).

Deep-rooted seedlings may avoid drought through access to moist soil layers (Padilla and Pugnaire 2007; León et al. 2011). Consequently, the ability to increase rooting depth in response to drought is adaptive in some species (Reader et al. 1993; Liu et al. 2000) and increases yield in many crops (Lobet et al. 2014). This ability differs, however, between species and environments, as a number of species show limited plasticity in rooting depth to water availability (Nicotra et al. 2002; Padilla and Pugnaire 2007; Bristiel et al. 2019). This may indicate a transition from plastic to fixed root growth strategies with decreasing water ability, selecting for specialists with fixed strategies under drier conditions (Bongers et al. 2017; Bristiel et al. 2019) Hence, the ability to adjust rooting patterns depends on the specific adaptations of a given species. In addition, seedling ontogeny and resource status may constrain seedling plasticity (Pigliucci 1998; Kitajima and Myers 2008), but this issue has received little attention.

The importance of root growth strategies for seedling performance is not well understood as essential information is lacking on trait variation and plasticity of seedling root systems. It is also not well known how such variation and plasticity are related to drought intensity and duration and how they influence water uptake and plant survival. Detailed information on these aspects will contribute to a predictive trait based ecology (Funk et al. 2017). Our study addresses this knowledge gap by documenting the ability of young grass seedlings to adjust their root system architecture, root morphology and biomass allocation to roots under progressive drought. We tested the specific predictions that seedlings under drought would: 1) increase biomass allocation to roots, 2) produce deeper roots, 3) increase investment in total root length, 4) reduce investment in biomass per unit root length and 5) develop a simpler root branching pattern. Since such responses to drought are potentially species-specific, we also tested for differences among species to distinguish species-specific and general patterns.

\section{Materials and methods}

\section{Study species}

To test our predictions, we selected a set of five common grasses within the Poaceae subfamily Pooideae used in ecological restoration of disturbed soils from lowland to alpine regions in northern Europe: Avenella flexuosa (L.) Drejer, Festuca ovina ssp. ovina L., Poa alpina L., Phleum alpinum L. and Agrostis mertensii Trin. All species grow in nutrient-poor systems, although $\mathrm{Poa}$ alpina may also be found on richer soils. They have a 
preference for contrasting habitats along a humidity gradient, where A. flexuosa and F. ovina occupy drier sites, $P$. alpina and $P$. alpinum grow under mesic conditions while $A$. mertensii is more frequent in mesic to moist conditions. The study was not designed to test differences in adaptations between species of different habitats, but to identify common root morphological responses to drought stress. These species share a Festucoid seedling morphology with a primary root system developing from the embryo, which is later replaced by a secondary root system emerging from tiller bases. Seeds were obtained from alpine to subalpine populations in southern Norway as part of a larger project addressing the use of site-specific plant material for ecological restoration.

\section{Experimental set up}

Seedling growth of these grasses under drought was studied in soil columns under controlled conditions with destructive harvest at regular intervals. Individual seedlings of the five species were established from seed in $40 \mathrm{~cm}$ tall $(7.5 \mathrm{~cm}$ diameter) columns filled with a coarse sand. The sand substrate used had a grain size distribution of 70\% $0.25-2 \mathrm{~mm}$ particles, $92 \% 0.125-$ $4 \mathrm{~mm}, 6 \%>4 \mathrm{~mm}$ and $2 \%<0.125 \mathrm{~mm}$ with a field capacity of $0.28 \mathrm{~kg}$ per litre of soil. The species-bytreatment combinations were randomised on column positions in wooden racks (12 rows by 22 positions) and let standing on a metal grating for drainage. The seedlings were grown for 10 days before the sand in each column was watered to runoff three times with a half-strength Hoagland nutrient solution and watering stopped in columns receiving the drought treatment. Control columns were watered to runoff four times per week with a 0.25 strength Hoagland solution. All soil columns were maintained under controlled conditions with light intensity of $400 \mu \mathrm{mol} \mathrm{m} \mathrm{m}^{-2} \mathrm{~s}^{-1}$ PAR (using a combination of fluorescent tubes and HPS lamps), $15^{\circ} \mathrm{C}$ air temperature and $18 \mathrm{~h}$ day length. The experimental design included five species by two watering treatments by 28 replicates, resulting in 280 columns in total.

One or two columns per treatment and species were harvested at 2-4 days intervals over eight weeks. To sample evenly across seedling sizes in all treatments, we started to harvest plants in the control one week earlier than in the drought treatment, and the harvest of the drought treatment was extended for up to two weeks longer than the last harvest of the control plants.

\section{Measurements}

After harvest, roots were washed free of substrate and scanned in $3 \mathrm{~mm}$ water at 600 dpi using an Epson Perfection V700 calibrated dual lens scanner and WinRhizo software (Regent Instruments Inc., Québec, Canada). After scanning, plant material was dried at $70{ }^{\circ} \mathrm{C}$ for $48 \mathrm{~h}$ and weighed. Rooting depth was estimated as the length of the longest root axis. Primary (seminal) and secondary (nodal, adventitious) roots were weighed and analysed separately. Root length of primary and secondary roots, total root length, total root surface area, total root volume and branching patterns were analysed using the WinRhizo software. Specific root length (SRL, $\mathrm{m} \mathrm{g}^{-1}$ ) and root tissue density (RTD, $g$ $\mathrm{cm}^{-3}$ ) were estimated for primary and secondary roots. Segment lengths, total length of main axis, total length of lateral and higher order roots per unit length of main axis, system altitude and magnitude (where altitude is the number of links of the longest path from the shoot to a root tip and magnitude is total number of root tips in the root system) were estimated using the Link and Development functions in WinRhizo for seedlings harvested 15-17 days after the start of the drought treatment. At this early stage, seedlings of drought and control treatments had the same size. The number of replicates for these analyses varied between three and four. Topological index (calculated as log (altitude)/log (magnitude)) was estimated for individual root systems as an indicator of root system topology (Glimskär 2000). Maximum quantum efficiency of PSII photochemistry $\left(\mathrm{F}_{\mathrm{v}} / \mathrm{fm}\right)$ was measured on dark-adapted leaves just before harvest for all columns and for a fixed set of ten columns per treatment and species for late harvests using a FMS2 Fluorescence Monitoring System (Hansatech Instruments Ltd., King's Lynn, UK). Leaf water content was determined for the whole shoot at column harvest date, starting four weeks after drought initiation when $\mathrm{F}_{\mathrm{v}} / \mathrm{fm}$ measurements indicated incipient stress. Phenotypic plasticity was estimated as the Relative Distances Plasticity Index (RDPI, Valladares et al. 2006) using the 'plasticity' R package (Ameztegui 2017) to compare individuals across treatments within species with total biomass in the range median biomass $\pm 1 / 3$ of median biomass, except for the topological responses where the same subset as above was used. RDPI was computed using sums of relative pairwise distances in trait values across all individuals of the same species occurring in different environments (here 
drought and control treatments). RDPI values range between 0 (low plasticity) and 1 (high plasticity) (Valladares et al. 2006).

Soil water potential of a subset of the columns with Festuca ovina was measured at harvest using MPS-6 calibrated water potential sensors connected to an Em50 data logger (Decagon Devices Inc., Pullman WA, USA). Sensors were inserted in the middle of 5 or $10 \mathrm{~cm}$ segments of the sand column and the water potential was recorded when values remained stable for $5 \mathrm{~min}$. These measurements showed that the drought treatment gave a steady lowering of the drying front during the experiment (Fig. 1). Volumetric water content was measured in the bottom of the columns at harvest, and these measurements gave no indications that the temporal changes in soil water content differed between species.

\section{Statistical analyses}

The allometric scaling exponent was estimated as the slope of the relationship $\ln y=\ln \beta+\alpha \ln x$ between pairs of traits $(x, y)$ by standardised major axis regression (Warton et al. 2006) using the standardized major axis estimation and testing routines (smatr) package (Falster et al. 2006) in R version 3.1.2 (R Core Team 2014). This method was applied to determine the relationships between root biomass and shoot biomass, total root length and shoot biomass, root length and root biomass for primary and secondary roots, total root surface and total root volume. Differences in allocation patterns between drought and control conditions were investigated by comparing the slope of these relationships within species, again using the 'smatr' package. All data for these regressions except for rooting depth were $\ln$ transformed prior to analysis to obtain homogenous variance.

Relative growth rate ( $\left.R G R, d^{-1}\right)$ was estimated as the slope of $\ln$ total biomass over time using ordinary least squares regression. Differences in RGR between control and drought conditions within species were tested in linear models with treatment as a categorical variable and time as continuous variable using the ' $\mathrm{lm}$ ' function in R. A significant treatment-by-time interaction indicates differences in RGR among treatments. The species-by-time interaction calculated separately for each treatment (drought or control) was used to evaluate RGR differences between species.

Linear models (ANOVA) were also used to test for differences in root tissue density and specific root length between drought and control treatments in each species and between primary and secondary roots. Shoot biomass was included as a continuous variable to correct for size differences. Further, a linear model with treatment and species as fixed factors was used to test for drought responses in root system architecture (total lateral and tertiary (higher order) root length per unit major root axis, average root diameter of main axis, root system topology and magnitude, and the average segment (link) length of the main axis). One-way ANOVA models were used to test for differences in RDPI between species in the 'plasticity' package, followed by Tukey HSD tests. Eight individuals were removed from the dataset, due to incomplete root recovery based on strongly deviating root fractions of total biomass. Model diagnostics were performed with normal probability plots and plots of residuals vs. fitted values.

To identify latent factors related to root growth strategies, an exploratory factor analysis was done for the dataset of seedlings harvested 15-17 days into the drought treatment incorporating variables describing size, biomass allocation, root system architecture and root morphology. This dataset is small with data only for 32 individuals. The analysis was run in Minitab 18 on the correlation matrix with a varimax rotation and factors extracted using principal components. Factors with unrotated eigenvalues $>1$ were kept. This selection was also confirmed using a parallel analysis with the nFactors package in R (Raiche and Magis 2015). The Kaiser-Meyer-Olkin test for factor adequacy was used to remove variables not suited for the factor analysis.

\section{Results}

Drought effects on relative growth rates

All species had considerably lower RGRs under drought (Fig. 2, Table S1) with mean ranges increasing from $0.035-0.055 \mathrm{~d}^{-1}$ under drought to $0.122-0.142 \mathrm{~d}^{-1}$ under watered conditions. RGR did not differ between species under similar environmental conditions (Table S1, Fig. 2). During the experiment, seedling biomass increased from 0.5 to 60 and $107 \mathrm{mg}$ for Agrostis mertensii under drought and control conditions, from 0.6 to 66 and $85 \mathrm{mg}$ in Avenella flexuosa, from 1.3 to 50 and $106 \mathrm{mg}$ in Festuca ovina, from 2.0 to 98 and $215 \mathrm{mg}$ in Phleum alpinum, and 0.5 to 42 and $177 \mathrm{mg}$ in Poa alpina, but control plants were harvested at a 


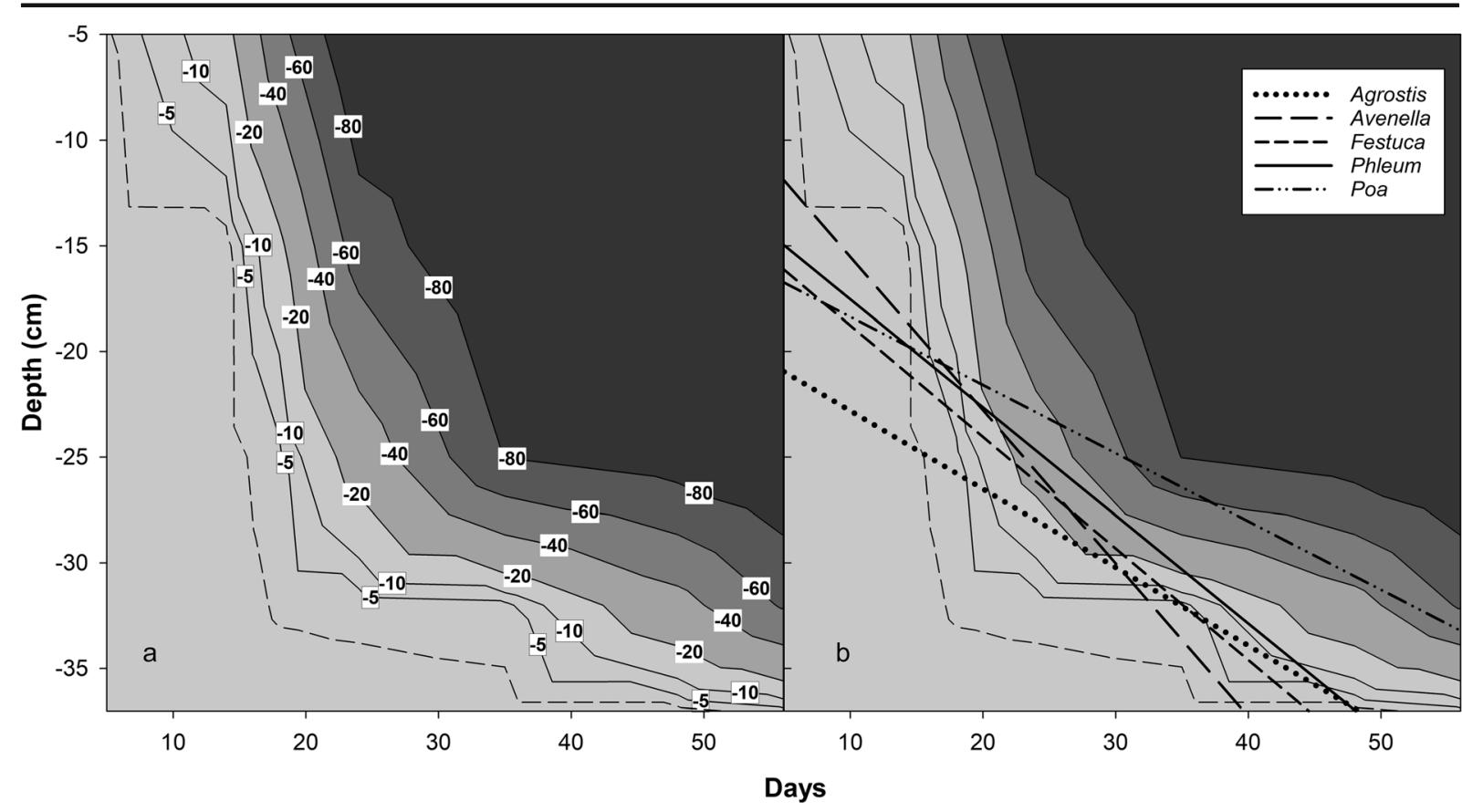

Fig. 1 Contour plot of the soil matric potential (MPa) as a function of soil depth and days since withholding of water measured in columns with Festuca ovina seedlings (a). The dashed contour line shows the general permanent wilting point of $-1.5 \mathrm{MPa}$. In (b),

younger age than droughted plants (Fig. 2). Hence, biomass produced under drought was 56, 77, 46, 45 and $24 \%$ of biomass produced in controls for the respective species.

\section{Chlorophyll fluorescence and relative water content}

Most plants in the drought treatment were able to maintain a relative water content (RWC) in the leaves of about $90-95 \%$ throughout the 8 weeks without watering. The only exception was Phleum alpinum, in which the relative water content dropped below $83 \%$ and the maximum quantum efficiency of PSII photochemistry $\left(\mathrm{F}_{\mathrm{v}} / \mathrm{fm}\right)$ dropped below 0.8 after 4 weeks of drought. However, RWC and $\mathrm{F}_{\mathrm{v}} / \mathrm{fm}$ did not drop any further and showed a slight increase later in the experiment. The remaining species all maintained $\mathrm{F}_{\mathrm{v}} / \mathrm{fm}$ ratios above 0.83 , even at the last harvest, indicating no effect of water availability on the maximum quantum efficiency of PSII photochemistry. Figure 1 indicated that rooting depth development did not keep pace with the lowering of the drying front from around day 17 after withholding water, but this was not reflected by the RWC and $\mathrm{F}_{\mathrm{v}} / \mathrm{fm}$ measurements (with the exception of

observations of rooting depth are plotted against days for Agrostis mertensii, Avenella flexuosa, Festuca ovina, Phleum alpinum and Poa alpina on the profile of soil matric potential obtained for F. ovina

Phleum alpinum mentioned above). No mortality was observed during the experiment.

Biomass allocation patterns

There was a significant effect of drought on the allometric relationships between root and shoot biomass in Avenella flexuosa and Festuca ovina and seedlings that experience drought had less root biomass relative to shoot biomass compared to seedlings in the watered control (Table 1). Phleum alpinum and Poa alpina also showed a decrease in biomass allocation to roots under drought but differences were only marginally significant ( $P=0.055$ and $P=0.069$, respectively). In the watered control columns, the slope of the root:shoot biomass curve was equal to 1 in all species except Avenella flexuosa, which allocated less biomass to roots than to shoots even under well-watered conditions (Table 1).

\section{Root length and rooting depth}

There were no differences in the total root length per unit shoot biomass between drought and watered control columns in any of the five species (Table 1). Rooting 


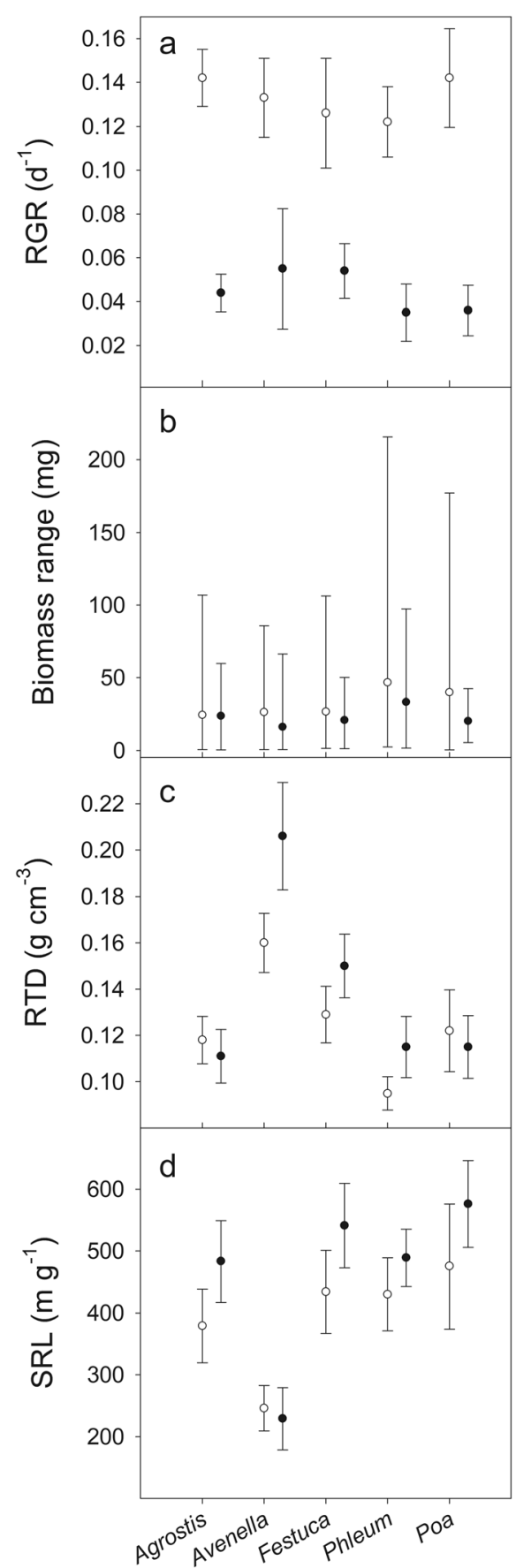

Fig. 2 Estimates of seedling relative growth rate (a, RGR), root tissue density (c, RTD) and specific root length (d, SRL) of the whole root system (means with $95 \%$ confidence intervals) and the range of seedling biomass (b) recorded in the experiment in five grasses (Agrostis mertensii, Avenella flexuosa, Festuca ovina, Phleum pratense and Poa alpina) under drought (black symbols) and watered control conditions (white symbols) depth was, however, more responsive to water availability than total root length (Fig. 3, Table 1). Plants experiencing drought had deeper roots at a given shoot size than control plants in all species. The effect got stronger as drought intensified throughout the experiment.

Primary and secondary root growth

A complete lack of secondary root formation under drought was a common response for all species. Secondary roots were not initiated and seedlings relied solely on their primary roots for water supply under drought. Under control conditions, however, the species exhibited different root growth strategies and secondary roots started to appear 22-24 days after germination in Agrostis mertensii, Phleum alpinum and Poa alpina, at 28 days in Festuca ovina and at about 40 days in Avenella flexuosa. Seedlings of the latter species showed great differences between individuals, with a few individuals producing secondary roots earlier and at smaller size. The sampling strategy did not allow for tests of species effects on time until emergence. Threshold shoot size for initiation of secondary roots varied from $2 \mathrm{mg}$ in F. ovina and P. alpina to $3 \mathrm{mg}$ in A. mertensii, $5 \mathrm{mg}$ in P. alpinum and $20 \mathrm{mg}$ in A. flexuosa (not shown).

Root length in relation to root biomass and surface

The allometric coefficient for the relationship between length and biomass of primary roots was consistently higher than 1 under drought conditions in all species, but only Phleum alpinum and Poa alpina displayed a significant response to drought. These species showed significantly higher investment in root length per unit root biomass of the primary roots under drought conditions than the control (Table 1). Agrostis mertensii, Avenella flexuosa and Festuca ovina displayed less flexible strategies, with relatively more root length per unit root biomass under both sets of growing conditions. Secondary roots had a lower SRL than the primary roots (Table 2), causing a considerably lower total root length per unit root biomass for the whole root system under control conditions compared to the drought conditions where the root system only consisted of primary roots. 
Table 1 Estimates of the linear relationship between expression of phenotypic properties and $95 \%$ confidence intervals of the estimates in five grasses growing under control (watered) and drought conditions using standardised major axis regressions

\begin{tabular}{|c|c|c|c|c|c|c|c|c|}
\hline \multirow[b]{2}{*}{ Species } & \multicolumn{3}{|l|}{ Control } & \multicolumn{3}{|l|}{ Drought } & \multicolumn{2}{|c|}{ Test for unequal slopes } \\
\hline & Slope & $95 \% \mathrm{CI}$ & $r^{2}$ & Slope & $95 \% \mathrm{CI}$ & $r^{2}$ & LRS & $\mathrm{P}$ \\
\hline \multicolumn{9}{|c|}{ Root biomass vs shoot biomass } \\
\hline Agrostis mertensii & 0.959 & $0.829-1.110$ & 0.90 & 0.769 & $0.600-0.985$ & 0.66 & 2.379 & 0.122 \\
\hline Avenella flexuosa & 0.823 & $0.747-0.907$ & 0.94 & 0.593 & $0.459-0.765$ & 0.75 & 5.484 & 0.019 \\
\hline Festuca ovina & 1.011 & $0.876-1.167$ & 0.87 & 0.785 & $0.665-0.927$ & 0.85 & 5.192 & 0.023 \\
\hline Phleum alpinum & 0.954 & $0.825-1.102$ & 0.88 & 0.734 & $0.584-0.924$ & 0.68 & 3.675 & 0.055 \\
\hline Poa alpina & 1.097 & $0.963-1.249$ & 0.90 & 0.871 & $0.701-1.082$ & 0.72 & 3.297 & 0.069 \\
\hline \multicolumn{9}{|c|}{ Total root length vs shoot biomass } \\
\hline Agrostis mertensii & 0.900 & $0.826-0.982$ & 0.96 & 0.897 & $0.770-1.046$ & 0.87 & 0.002 & 0.969 \\
\hline Avenella flexuosa & 0.936 & $0.843-1.040$ & 0.93 & 0.983 & $0.841-1.148$ & 0.91 & 0.175 & 0.676 \\
\hline Festuca ovina & 1.008 & $0.815-1.246$ & 0.91 & 0.997 & $0.906-1.097$ & 0.95 & 0.009 & 0.924 \\
\hline Phleum alpinum & 0.873 & $0.774-0.985$ & 0.93 & 0.842 & $0.716-0.990$ & 0.84 & 0.001 & 0.977 \\
\hline Poa alpina & 1.023 & $0.929-1.129$ & 0.95 & 1.187 & $0.966-1.459$ & 0.76 & 0.278 & 0.598 \\
\hline \multicolumn{9}{|c|}{ Rooting depth vs shoot biomass } \\
\hline Agrostis mertensii & -6.511 & $-7.76--5.47$ & 0.85 & -7.411 & $-10.37--5.29$ & 0.46 & 0.476 & 0.490 \\
\hline Avenella flexuosa & -6.166 & $-7.42-5.12$ & 0.80 & -8.545 & $-10.78--6.77$ & 0.79 & 4.498 & 0.029 \\
\hline Festuca ovina & -6.11 & $-7.52--4.98$ & 0.73 & -8.915 & $-10.12--7.86$ & 0.92 & 11.54 & $<0.001$ \\
\hline Phleum alpinum & -5.723 & $-7.15--4.58$ & 0.70 & -11.029 & $-14.08--7.51$ & 0.44 & 8.919 & 0.003 \\
\hline Poa alpina & -5.310 & $-6.34--4.45$ & 0.82 & -10.733 & $-15.40--7.48$ & 0.41 & 9.652 & 0.002 \\
\hline \multicolumn{9}{|c|}{ Length vs biomass of primary roots } \\
\hline Agrostis mertensii & 1.077 & $0.938-1.237$ & 0.91 & 1.361 & $1.112-1.665$ & 0.79 & 3.633 & 0.057 \\
\hline Avenella flexuosa & 1.326 & $1.194-1.473$ & 0.94 & 1.585 & $1.353-1.856$ & 0.90 & 3.529 & 0.060 \\
\hline Festuca ovina & 1.142 & $1.011-1.291$ & 0.91 & 1.269 & $1.127-1.430$ & 0.92 & 1.571 & 0.210 \\
\hline Phleum alpinum & 0.965 & $0.811-1.148$ & 0.82 & 1.256 & $1.039-1.520$ & 0.79 & 4.159 & 0.041 \\
\hline Poa alpina & 0.929 & $0.785-1.099$ & 0.85 & 1.245 & $1.073-1.444$ & 0.87 & 6.558 & 0.010 \\
\hline \multicolumn{9}{|c|}{ Total root length vs total root biomass } \\
\hline Agrostis mertensii & 0.939 & $0.836-1.054$ & 0.93 & 1.361 & $1.112-1.665$ & 0.79 & 9.342 & $<0.001$ \\
\hline Avenella flexuosa & 1.079 & $0.964-1.206$ & 0.93 & 1.585 & $1.353-1.857$ & 0.90 & 13.37 & $<0.001$ \\
\hline Festuca ovina & 0.865 & $0.769-0.974$ & 0.91 & 1.269 & $1.127-1.430$ & 0.92 & 18.05 & $<0.001$ \\
\hline Phleum alpinum & 0.886 & $0.776-1.010$ & 0.90 & 1.256 & $1.039-1.520$ & 0.79 & 8.588 & 0.003 \\
\hline Poa alpina & 0.869 & $0.755-1.000$ & 0.89 & 1.245 & $1.073-1.444$ & 0.87 & 11.400 & $<0.001$ \\
\hline \multicolumn{9}{|c|}{ Root surface area vs root length } \\
\hline Agrostis mertensii & 1.037 & $1.012-1.063$ & 0.99 & 0.979 & $0.895-1.071$ & 0.96 & 1.561 & 0.211 \\
\hline Avenella flexuosa & 0.978 & $0.942-1.016$ & 0.99 & 0.859 & $0.808-0.913$ & 0.98 & 11.25 & $<0.001$ \\
\hline Festuca ovina & 1.049 & $1.009-1.090$ & 0.99 & 0.961 & $0.921-1.002$ & 0.99 & 9.048 & 0.003 \\
\hline Phleum alpinum & 1.041 & $1.015-1.069$ & 0.99 & 0.968 & $0.909-1.031$ & 0.98 & 4.448 & 0.035 \\
\hline Poa alpina & 1.070 & $1.039-1.103$ & 0.99 & 1.003 & $0.951-1.057$ & 0.98 & 4.570 & 0.032 \\
\hline
\end{tabular}

Combinations of phenotypic properties are listed as (Y, X) pairs. All responses except rooting depth were ln-transformed. Differences in slope between drought and control (watered) conditions were tested using a likelihood ratio statistic $(\mathrm{LRS} ; \mathrm{df}=1)$

The higher proportion of thicker secondary roots under control conditions gave more root surface area per unit root length in four of the species in the control columns (Table 1). There were, however, no differences in the relationship between primary root surface area and primary root length between treatments (data not shown). 


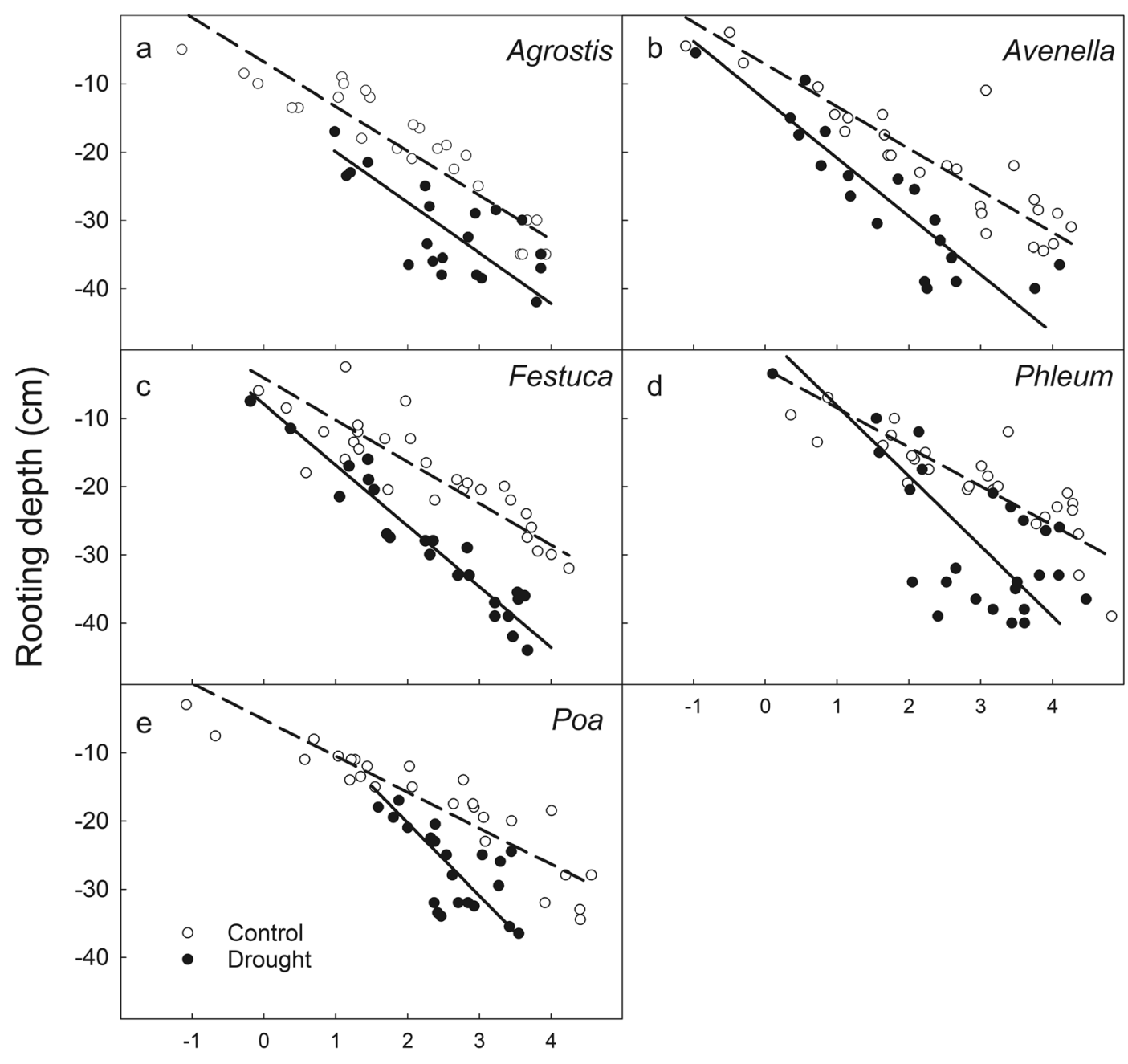

\section{Shoot biomass (mg, In transformed)}

Fig. 3 Relationship between seedling shoot biomass (lntransformed) and maximum rooting depth $(\mathrm{cm})$ under control (watered) and drought conditions in five grasses: Agrostis mertensii (a), Avenella flexuosa (b), Festuca ovina (c), Phleum

Specific root length and root tissue density

Specific root length (SRL) of the whole seedling root system increased with time and plant size under drought in all species, while it showed no response or a slow decline in the control (regressions not shown). Correcting for plant size, the drought treatment gave higher SRL than the control in Festuca ovina only (Table S2). Avenella flexuosa had a lower SRL than the other species under both sets of conditions (Table S3, Fig. 2). Primary roots had a much higher SRL than secondary roots in the control columns alpinum (d) and Poa alpina (e). Regression lines are the result of standardised major axis regression models for each of the treatments

(Tables 2, S3), causing the differences in SRL observed between drought and control treatments.

Except for a weak declining trend in root tissue density (RTD) with time in the drought treatment, there were no clear patterns in RTD with respect to plant size and time. Avenella flexuosa had a higher RTD than the other species in both control and drought conditions (Tables 2, S2), explaining the lower SRL observed in this species. Festuca ovina also had a higher RTD than the remaining three species but only under drought. RTD was higher in the drought treatment in A. flexuosa, F. ovina and Phleum alpinum compared to 
Table 2 Specific root length (SRL, $\mathrm{m} \mathrm{g}^{-1}$ ) of primary and secondary roots of five grasses grown under near-optimal control (watered) conditions

\begin{tabular}{lllllll}
\hline & \multicolumn{2}{l}{ Primary roots } & & \multicolumn{2}{l}{ Secondary roots } \\
\cline { 2 - 3 } \cline { 6 - 7 } Species & Mean & $95 \%$ CI & & Mean & $95 \%$ CI \\
\hline Agrostis mertensii & 592.9 & $528.0-674.5$ & & 117.8 & $77.3-165.2$ \\
Avenella flexuosa & 421.6 & $319.0-533.6$ & & 56.71 & $45.00-84.34$ \\
Festuca ovina & 755.3 & $669.9-861.8$ & & 147.4 & $78.5-194.5$ \\
Phleum alpinum & 639.1 & $473.0-766.6$ & & 131.0 & $89.0-180.5$ \\
Poa alpina & 730.4 & $515.9-995.8$ & & 175.3 & $122.9-233.7$ \\
\hline
\end{tabular}

Information on primary roots under drought are found in Table S1. Secondary roots were not produced under drought. Statistical tests of differences SRL between primary and secondary roots were all highly significant $(P<0.001)$

the control because of an increasing proportion of secondary roots with a considerably lower RTD than primary roots (range $0.025-0.042 \mathrm{~g} \mathrm{~cm}^{-3}$ across species) in the control treatment. However, the response to drought differed between species (species by treatment interaction: $\mathrm{F}=3.92, P<0.004)$ and for $A$. mertensii and $P$. alpina no effect of drought on RTD was observed. For the primary roots alone, the five species had a similar increase in RTD under drought. Interestingly, the mean root diameter did not differ between species and was not responsive to drought (Table 3).

Branching pattern (topology) of primary roots

The complexity of the root systems differed between species (Figs. 4 and 5, Tables 3). The simple root system of Avenella flexuosa and Festuca ovina were characterised by a main axis with a few branches (long segments, low magnitude, short laterals and few root tips). Phleum alpinum, Agrostis mertensii

Table 3 ANOVA table (with F test statistics and $p$ values) of the seedling response in root architecture to drought in a set of five grasses measured as total lateral and tertiary (higher order) root and Poa alpina had more branched root systems with different combinations of longer lateral roots, more and longer tertial roots and higher root system magnitude (Figs. 4, 5, S1). The largest differences were between A.flexuosa and P. alpinum that differed for most significant terms (Table S4).

Seedlings experiencing drought had fewer and shorter higher-order roots and a higher topological index than seedlings in the control treatment (Fig. 4, Table 3). These responses indicated a change towards a more herringbone-like structure of the (primary) root system under drought, an effect that was most pronounced in A. flexuosa and F. ovina (Fig. 4). A plot of the $\log$ altitude - log magnitude relationship also illustrated seedling root systems of these species to be closer to a herringbone than to a dichotomous branching pattern (Fig. 6) also apparent in the root-scan pictures (Fig. 5). The effect of drought on the formation of lateral and higher order roots, the topological index, root system magnitude, root diameter and segment length did not differ between species (i.e. no species by drought interaction, Table 3).

\section{Phenotypic plasticity}

Phenotypic plasticity in several of the (aggregated) root traits and responses differed between species (Table 4, Fig. 4). Plasticity in magnitude and segment length of the main axis did not differ across species, while Agrostis mertensii had a higher plasticity in altitude (Fig. 4).

Root branching patterns as described by the topology index (log altitude/log magnitude ratio) displayed higher plasticity in Avenella flexuosa and Festuca ovina as compared to Agrostis mertensii. Rooting depth and root system magnitude had the most plastic response to

length per unit major root axis, average root diameter of main axis, root system topology and magnitude, and the average segment (link) length of the main axis. Total $\mathrm{df}=33, \mathrm{df}$ residuals $=24$

\begin{tabular}{|c|c|c|c|c|c|c|c|c|c|c|c|c|c|c|}
\hline \multirow[b]{2}{*}{ Source } & \multicolumn{2}{|c|}{ Lateral roots } & \multicolumn{2}{|c|}{ Tertiary roots } & \multicolumn{2}{|c|}{ Topology index } & \multicolumn{2}{|c|}{ Altitude } & \multicolumn{2}{|c|}{ Magnitude } & \multicolumn{2}{|c|}{ Diameter } & \multicolumn{2}{|c|}{ Segment length } \\
\hline & $\mathrm{F}$ & $\mathrm{p}$ & $\mathrm{F}$ & $\mathrm{p}$ & $\mathrm{F}$ & $\mathrm{p}$ & $\mathrm{F}$ & $\mathrm{p}$ & $\mathrm{F}$ & $\mathrm{p}$ & $\mathrm{F}$ & $\mathrm{p}$ & $\mathrm{F}$ & $\mathrm{p}$ \\
\hline Species & 4.44 & 0.008 & 3.48 & 0.022 & 4.24 & 0.010 & 4.36 & 0.009 & 3.53 & 0.021 & 0.81 & 0.534 & 1.86 & 0.152 \\
\hline Drought & 2.94 & 0.099 & 8.56 & 0.007 & 13.92 & 0.001 & 5.97 & 0.023 & 1.22 & 0.281 & 0.21 & 0.651 & 0.32 & 0.576 \\
\hline$S \times D$ & 1.32 & 0.291 & 0.92 & 0.468 & 1.15 & 0.357 & 4.16 & 0.011 & 2.43 & 0.075 & 2.04 & 0.122 & 1.44 & 0.253 \\
\hline $\mathrm{R}^{2}$ adj & 32 & & 37 & & 43 & & 51 & & 35 & & 6 & & 16 & \\
\hline
\end{tabular}




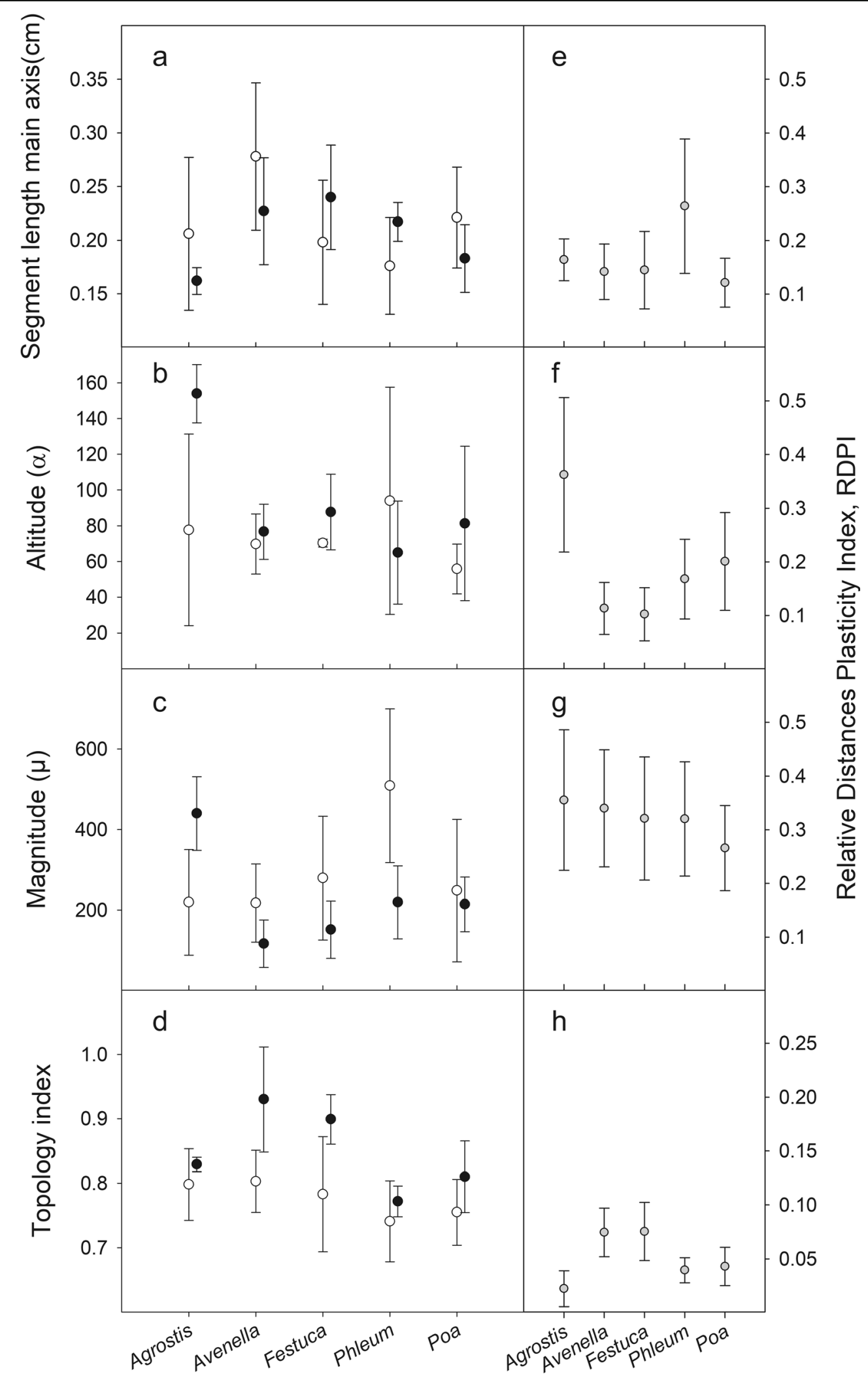


Fig. 4 A. Estimates of root system topology parameters (a-d, mean and $95 \%$ confidence interval) of a subset of even-sized seedlings under watered control (white symbols) and drought (black symbols) conditions 15-17 days after the start of drought treatment. For the same topology parameters, phenotypic plasticity estimated as the relative distance plasticity index with $95 \% \mathrm{CI}$ is shown (e-h, gray symbols). Results are shown for Agrostis mertensii, Avenella flexuosa, Festuca ovina, Phleum alpinum and Poa alpina

drought, while the topological index was the least plastic (Table 4).

Trait correlations patterns

The explorative factor analysis found three latent factors that together described $81 \%$ of the variation in the dataset (Fig. 7). The first factor was related to a trade-off between SRL and RTD, including also a positive relationship between rooting depth, topological index and RTD. The second factor was linked to the negative relationship between link lengths and both root magnitude and altitude, where a longer link length (distance between branching) associated with a lower number of segments between shoot and root tips, and fewer root tips. The third factor was related to size and biomass allocation patterns with a negative relationship between root fraction of total biomass and shoot biomass. Factor 1 aligned well with differences between watered and drought conditions, while factors 2 and 3 contained some less clear-cut differences between species (Fig. 7).

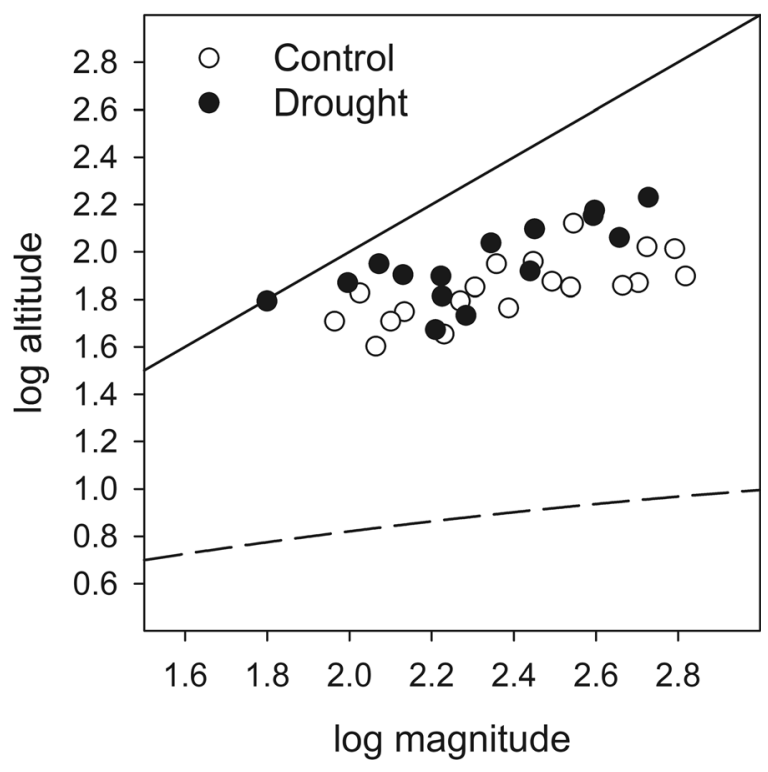

Fig. 6 The relationship between seedling primary root system magnitude and altitude under control and drought conditions 1517 days after the start of drought treatment in a set of five grass species. Reference lines illustrates a typical herringbone branching topology (solid line, topological index of 1) and a dichotomous branching topology (dashed line, altitude $=\log _{2}$ (magnitude $)$ )

\section{Discussion}

Root growth strategies of seedlings are important for their survival and establishment, but are not sufficiently known to contribute to a predictive trait based ecology. Here we provide new insight into grass seedling responses to progressing drought through changes in root traits. These traits included architecture, morphology and biomass allocation patterns. Although we found low phenotypic

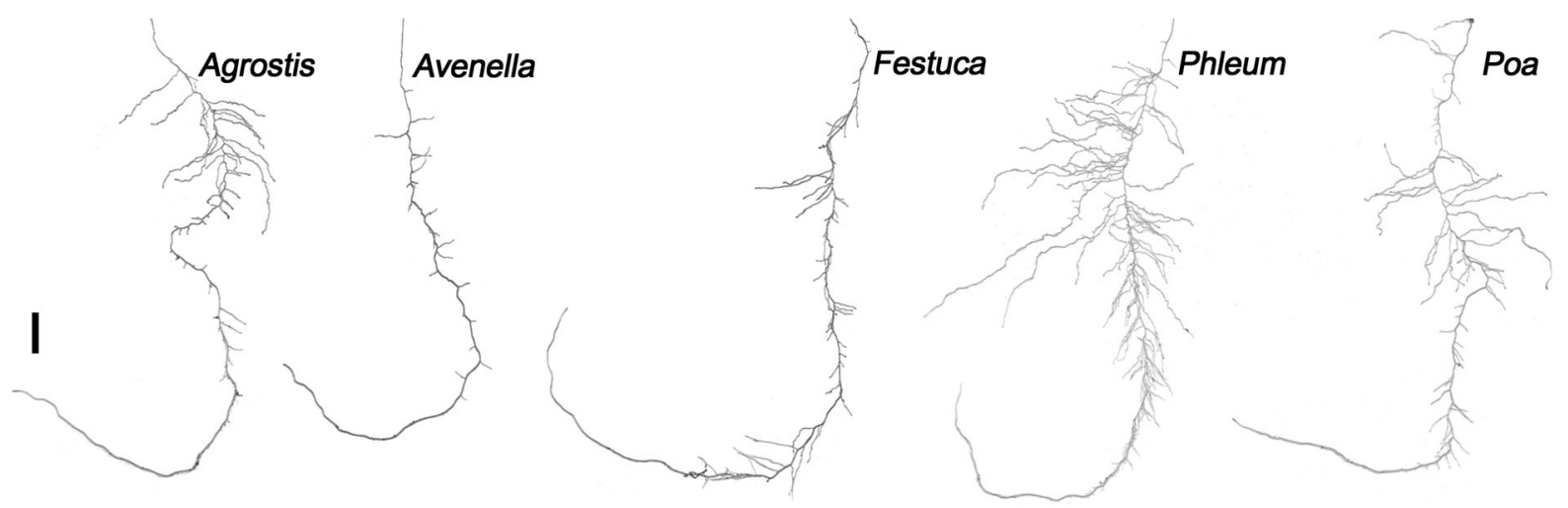

Fig. 5 Rootscans of representative even aged Agrostis mertensii, Avenella flexuosa, Festuca ovina, Phleum alpinum and Poa alpina seedlings 12-14 days after start of drought treatment. Black scale bar is $1 \mathrm{~cm}$ 
Table 4 Estimated mean relative distance plasticity index (RDPI, mean \pm SE) for plasticity of different root traits in response to drought and ANOVA test of differences in RDPI between species ( $F$ test statistics and $p$ values)

One-way ANOVA for differences among species

\begin{tabular}{|c|c|c|c|c|c|c|c|c|}
\hline \multirow[b]{2}{*}{ Root traits } & \multirow[b]{2}{*}{ RDPI } & & & & & & & \\
\hline & & $\mathrm{F}$ & $\mathrm{p}$ & \multicolumn{5}{|c|}{ Tukey HSD } \\
\hline & & & & Agrostis & Avenella & Festuca & Phleum & Poa \\
\hline Rooting depth & $0.257 \pm 0.010$ & 5.51 & 0.000 & $\mathrm{a}$ & $\mathrm{b}$ & $\mathrm{a}$ & $\mathrm{ab}$ & $\mathrm{a}$ \\
\hline Root fraction & $0.220 \pm 0.010$ & 1.49 & 0.207 & $\mathrm{a}$ & $\mathrm{a}$ & a & $\mathrm{a}$ & $\mathrm{a}$ \\
\hline Length primary roots & $0.195 \pm 0.010$ & 1.62 & 0.171 & $\mathrm{a}$ & $\mathrm{a}$ & a & $\mathrm{a}$ & $\mathrm{a}$ \\
\hline Total root length & $0.195 \pm 0.014$ & 5.53 & 0.000 & $\mathrm{~b}$ & $\mathrm{~b}$ & $\mathrm{a}$ & $a b$ & $\mathrm{~b}$ \\
\hline SRL primary roots & $0.226 \pm 0.010$ & 6.33 & 0.000 & $\mathrm{~b}$ & $\mathrm{a}$ & $a b$ & $\mathrm{~b}$ & $\mathrm{a}$ \\
\hline Root tissue density & $0.158 \pm 0.007$ & 9.99 & 0.000 & $\mathrm{bc}$ & $\mathrm{a}$ & $\mathrm{bc}$ & $\mathrm{c}$ & $\mathrm{b}$ \\
\hline Magnitude & $0.320 \pm 0.025$ & 0.37 & 0.827 & $\mathrm{a}$ & $\mathrm{a}$ & $\mathrm{a}$ & $\mathrm{a}$ & $\mathrm{a}$ \\
\hline Segment length & $0.167 \pm 0.017$ & 2.16 & 0.086 & $\mathrm{a}$ & $\mathrm{a}$ & $\mathrm{a}$ & $\mathrm{a}$ & $\mathrm{a}$ \\
\hline Altitude & $0.189 \pm 0.020$ & 5.45 & 0.001 & $\mathrm{a}$ & $\mathrm{b}$ & $\mathrm{b}$ & $\mathrm{b}$ & $\mathrm{ab}$ \\
\hline Topological index & $0.051 \pm 0.005$ & 4.84 & 0.002 & $\mathrm{~b}$ & $\mathrm{a}$ & $\mathrm{a}$ & $a b$ & $a b$ \\
\hline
\end{tabular}

Tukey HSD tests were used to test for differences between species. Treatment $\mathrm{df}=4 \mathrm{df}$ for residuals $=205$ ( 52 for root topological estimates)

plasticity of biomass allocation, root morphology and root system architecture, the plasticity of the primary root system allowed seedlings to track soil moisture and survive an 8-week dry-down period under controlled conditions. This was primarily an effect of increasing rooting depth, which was achieved without increased allocation of biomass to roots, and without contribution from the secondary root system as drought completely prevented the development of secondary roots.

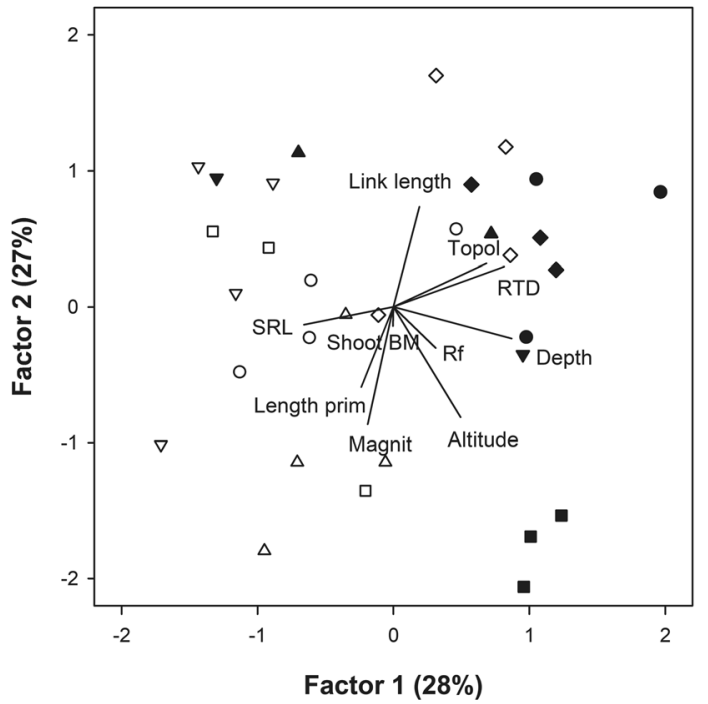

Fig. 7 Biplots of response variables and plant individuals on three factors extracted in an explorative factor analysis. Variables included were shoot biomass, root fraction of total biomass (Rf), total length of primary roots, rooting depth, magnitude of the base segment, average link length of the main axis, global altitude, topological index, specific root length (SRL) and root tissue

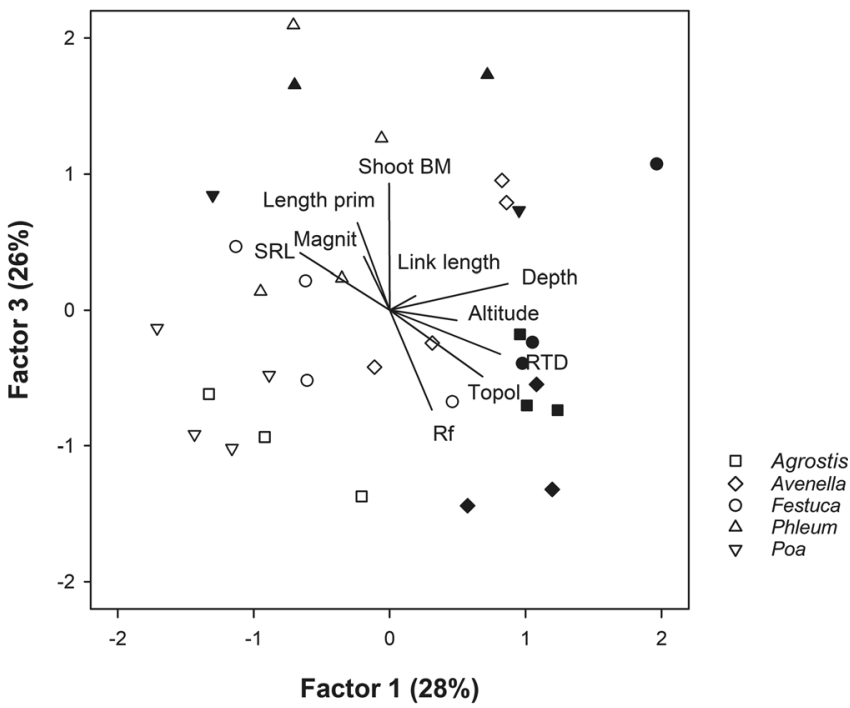

density (RTD) of the whole root system. Symbol shape represents species and symbol colour represents treatments with watered conditions (white symbols) or drought conditions (black symbols). The factors explained 28, 27 and $26 \%$ of the variation (80\% in total) and communalities varied between 0.58 and 0.94 
Biomass allocation strategies: Root vs. shoot under drought?

We found that relative allocation to root biomass dropped in two species or was unaffected by drought in the other three species. Hence, the prediction that drought would increase biomass allocation to roots was not supported by our results. These results contradicts previous studies as increased allocation to roots under drought has been frequently reported and root growth is often maintained for longer than shoot growth under drought, at least in moderately stressed plants (e.g. Volaire et al. 2014). These discrepancies are likely related to the capacity of seedlings to adjust as influenced by their ontogeny, available resources and characteristics of the drought event.

Plasticity of biomass allocation patterns can be expected to depend on available resources (Valladares et al. 2007; Kitajima and Myers 2008). As the drought intensified over a period of several weeks and as root to shoot signalling is sensitive and rapid (e.g. Davies and Bacon 2003), we expected responses to a lowering of the drying front early in the experiment, while water and other resources were still available. Although the seedlings were small, there were enough resources in the early stage to start adjusting the root investment.

There is a strong context dependence of root responses to drought exemplified by a number of studies including available resources versus the rate and intensity of drought, differences between seedling and mature stages, and the importance of adaptations both within and between species (e.g. Granier et al. 2006; Padilla et al. 2013; Kellermeier et al. 2013; Rosas et al. 2013). Drought imposes combined stress conditions, affecting water availability, nutrient uptake (e.g. Davies and Bacon 2003; Gonzalez-Dugo et al. 2012) and soil physical properties, e.g. soil strength, but also processes such as nutrient retranslocation within plants (Khasanova et al. 2013). Different species may use different tolerance and survival strategies (Khasanova et al. 2013; Paula and Pausas 2011) and the importance of specific root traits may well change as drought intensifies. Many studies have reported changes in root:shoot ratio or root fractions of total biomass under drought (Yang et al. 2005) and relationships between root:shoot ratio and drought avoidance (Huang et al. 2014). However, these effects are often difficult to interpret when size differences between treatments and ontogeny are not taken into consideration (Comas et al. 2013). In our study, we compared even-sized seedlings or used regression approaches to avoid this problem.

The context dependence also relates to the experimental approach (Poorter et al. 2012). We used sand columns simplifying harvest and root cleaning. However, we expect that responses may differ between soil types based on the actual movement of water in the soil matric, water potential and mechanical impedance of the soil. Further, the characteristics of the drought episode as affected by temperature, irradiance and wind may also influence the drought response. These factors can be manipulated or controlled in experimental approaches to increase our understanding of drought responses. The tested species occur in a wide range of soils with different contributions of silt, sand, gravel and organic material; some of them are also frequent on shallow soils. The sand columns had less fine material than most natural soils. So further research is needed to evaluate the importance of soil texture for seedling drought responses.

As the lack of increased allocation to root biomass was a consistent effect across species, we believe that this may be a common strategy for young perennial grass seedlings under drought stress, but the context dependency, especially ontogeny, available resources and the intensity and duration of drought episodes, needs to be explored before refined hypotheses of mechanism can be developed.

\section{Rooting depth and total root lengths}

Seedling rooting depth was one of the most plastic responses and increased with drought, while total root length per unit shoot biomass was not affected. This supports the prediction that seedlings of similar size produce deeper roots under drought, but not the prediction that seedlings would invest in more root length per shoot biomass under drought. These responses reflect the relative importance of rooting depth versus root length under drought. Although there was a positive relationship between total root length and water uptake when water was available, a deeper root system is more important for dehydration avoidance than total root length and root biomass (Huang et al. 2014). Surprisingly, Hoekstra et al. (2014) found no clear link between depth of water uptake and resistance to drought in a set of grassland species. This observation was supported by Bristiel et al. (2019) who found that characteristics of deep roots (diameter and root tissue 
density) better explained drought tolerance in Dactylis glomerata than rooting depth. Plants often have a suite of traits that provide a combination of dehydration avoidance and dehydration tolerance (Ludlow 1989; Johnson and Asay 1993; Volaire et al. 2014; Volaire 2018). Deeper roots provided a mechanism of dehydration avoidance for the seedlings and was, together with stomatal regulation of water loss, sufficient to maintain leaf turgor. We do not have data on stomata behaviour, but the strong reduction in biomass production indicates that stomata closure was a major mechanism to avoid dehydration. Dehydration affects a set of physiological and biochemical processes (Boyer 1982) and the photosynthetic system is sensitive to these changes. When changes are not too rapid or severe, there is an acclimation and protection of the PSII (e.g. Bi et al. 2016). Paired with our measurements of leaf water content and maximum efficiency of PSII photochemistry $\left(\mathrm{F}_{\mathrm{v}} /\right.$ $\mathrm{fm}$ ), we found that the allocation of root length to deeper roots allowed seedlings to kept track with the lowering of the water table and provide shoots with sufficient water throughout the 8-week drought period to prevent damages to the photosystem. Consequently, there were no mortality or wilting symptoms during the experiment. The $\mathrm{F}_{\mathrm{v}} / \mathrm{fm}$ parameter may however not be optimal to monitor changes in the photosystem functions, as its response may be slow until leaves approach a critical water status (e.g. Živčák et al. 2008).

\section{Secondary root system development}

Drought prevented the development of secondary roots in all species. In the control treatment, differences between species in initiation and growth of secondary roots of up to 18 days were found. In three of the species studied, the secondary roots started to develop so early in the control treatment that their absence in the drought treatment was surprising. This may indicate that dry conditions around the tiller base, prevented initiation and growth of secondary roots. The initiation and growth of secondary roots is rapid under optimal conditions, but both initiation and elongation have been found to decrease with low humidity in the soil surrounding the tiller base (Briske and Wilson 1978). Hence, under drought the development of secondary roots may be delayed for weeks (Bassiri et al. 1988; Wilson and Briske 1979). We conclude that available water in the upper few centimetres of the soil columns was too low for initiation of secondary roots, a conclusion supported by soil moisture measurements. Initiation and growth of secondary roots under dry conditions have, however, been observed in some annual grasses (Rostamza et al. 2013). We do not know whether these different patterns of secondary root growth are due to environmental conditions or phylogeny. To understand strategies of seedling root growth under drought, we thus need to investigate the environmental impact on initiation and growth of secondary roots under a wider set of environmental conditions and phylogenetic lines. Although primary roots often have a short life span and limited water transport ability compared to secondary roots (e.g. Wilson et al. 1976; Harada and Yamazaki 1993), they were the sole provider of water to the young seedlings under drought in this experiment.

\section{Morphological plasticity}

The primary root system had only a moderate plasticity in SLR and RTD in response to drought and root diameter was not affected. Such low plasticity of SRL and RTD in primary roots has also been found in response to nitrogen (Kong et al. 2010). As secondary roots only established under control treatment conditions, we were unable to document plasticity of SRL and RTD in secondary roots. Results from other studies of primary root growth in species of Festuca indicate that plasticity of SRL in secondary roots in response to drought is higher than in primary roots (Sun et al. 2013; Andrade et al. 2014), a relationships that needs further investigation. The finding of higher RTD and SRL of primary roots compared with secondary roots is in line with other studies (Kong et al. 2010). These differences in SRL and RTD between primary and secondary roots caused a considerable difference in average SRL and RTD between drought and control conditions for the whole root systems.

Avenella flexuosa had a considerably higher RTD, but lower SRL, than the other species. This pattern was consistent for both primary and secondary roots. In grasses, drought-tolerant species often have lower SRL than drought-sensitive species (Fort et al. 2013), indicating that $A$. flexuosa has a more conservative root growth strategy than Agrostis mertensii, Phleum alpinum and Poa alpina, with Festuca ovina having an intermediate strategy. A high SRL indicates longer roots per unit biomass invested (Cornelissen et al. 2003), which are capable of higher resource capture but with a shorter life-span (Gill and Jackson 2000; Fort et al. 2013). A low RTD is also associated with fast turnover 
(Ryser 1996). Moreover, such thin roots are more severely affected by drought (Davies and Bacon 2003).

Plasticity of root system architecture

Major components of root system architecture were affected by drought, but the phenotypic plasticity of most traits was low to moderate (RDPI values around 0.2 and below). The changes were towards a deeper, simpler, more herringbone-like root system (with a higher topological index) under drought. This was most prominent in Avenella flexuosa and Festuca ovina with a dominant major root axis with few short lateral roots, while the other species maintained a more complex architecture with more and longer lateral roots. These changes demonstrate a flexibility of biomass allocation within the primary root systems under drought in some of the species, expected to provide adaptive changes in root system architecture and selective advantages during establishment. Reduced lateral root initiation and growth is a common response to drought (e.g. Malamy 2005), although some studies report increased lateral root formation (Jupp and Newman 1987). Our results showed a reduction in lateral roots and root lengths in response to drought in some species (especially $F$. ovina and $A$. flexuosa), but an opposite pattern in others (A. mertensii). It is important to note that our estimates are based on responses of young seedlings after 15 days of drought treatment. Further investigations are needed to determine the constancy and potential phylogenetic or environmental signals of these patterns.

\section{Trait correlation patterns}

The first latent factor aligned with a trade-off between SRL and RTD, including also a positive relationship between rooting depth, topological index and RTD. This factor can be interpreted in the 'fast-slow' plant economics framework (Reich 2014) with a trade-off between traits contributing to water acquisition vs. water conservation. In this context, 'fast' water acquiring plants have thin roots with high SRL and low RTD while 'slow' water conserving plants have thick roots with high RTD and low SRL (e.g. Weemstra et al. 2016). The strong alignment of this factor with soil water conditions (Fig. 7) indicates a phenotypic adjustment of the root system. The positive relationships of RTD with rooting depth and topological index in our study further indicates that a simpler (and deeper) more herringbone like root system architecture is part of the 'slow' water conserving strategy. A similar relationship between SRL and RTD was found by Bristiel et al. (2019), but in their case root diameter differences played a larger role, RTD did not align as strongly with rooting depth, and SRL and maximum rooting depth did not align with the 'acquisition-conservation' axis. In our study root diameter of the primary root showed low plasticity, but differed between species.

Our second factor was linked to the negative relationship between link lengths and both root magnitude and altitude, where a longer link length (segment distance between branches) was associated with a lower number of segments between shoot and root tips, and fewer root tips. This negative relationship is simply a result of the interlinked architecture of root systems.

Our third factor aligned with biomass allocation patterns. A classical interpretation would be an increased biomass allocation to roots under moderate drought to acquire more water (Eziz et al. 2017), but as we found low plasticity in this trait, this factor likely represents differences in biomass allocation patterns between species. Based on the biplots in Fig. 7, there are tendencies that an interaction between species and soil water conditions affects the relationships between magnitude and altitude. This aspect could be further explored to understand the plasticity of root systems.

It is evident that root growth strategies are linked to whole-plant strategies (Reich 2014) through trait covariation suites or syndromes (Chapin et al. 1993; Freschet et al. 2018). Such syndromes affect both dehydration avoidance and dehydration tolerance in grasses (Bristiel et al. 2019) and relate to seedling growth forms and productivity in a wider set of species (Larson and Funk 2016). Our results contribute to the understanding of these relationships for seedlings for a small set of grass species, but a predictive trait based understanding of seedling performance under contrasting environmental conditions will require a larger effort. As a basis for species sourcing and robust ecological restoration, differences between species were smaller than expected. Providing a soil that allows development of deep roots, seems however to be essential.

\section{Conclusions}

Young grass seedlings were able to track soil moisture during progressive drought through deeper rooting, 
although phenotypic plasticity of biomass allocation, root morphology and root system architecture were only low or moderate. Drought resulted in deeper roots with shorter and fewer higher-order roots and a higher topological index indicating a change towards a more herringbone-like structure of the primary root system in all five species, although Agrostis mertensii showed some deviating patterns. These changes were sufficient to provide shoots with water over an eight-week period of progressing drought. Surprisingly, biomass allocation to roots decreased or was unaffected by drought. As development of secondary roots was arrested in all five species under drought, this plasticity of the primary root system may well be one of the key features for seedling survival in grasses under drought. Overall our results suggests that selection pressure on drought avoidance in early seedling stages may result in the use of adaptive morphological and architectural plasticity strategies in small-seeded species that are limited by the allocation of biomass to roots.

Acknowledgements This study was funded by The Research Council of Norway, grant no. 208204. The authors have no conflicts of interest to declare.

\section{References}

Alvarez-Flores R, Winkel T, Nguyen Thi Truc A, Joffre R (2014) Root foraging capacity depends on root system architecture and ontogeny in seedlings of three Andean Chenopodium species. Plant Soil 380:415-428. https://doi.org/10.1007 /s11104-014-2105-x

Ameztegui A (2017) Plasticity: an R package to determine several plasticity indices. GitHub repository, https://github. com/ameztegui/Plasticity

Andrade BO, Overbeck GE, Pilger GE, Hermann JM, Conradi T, Boldrini II, Kollmann J (2014) Intraspecific trait variation and allocation strategies of calcareous grassland species: results from a restoration experiment. Basic Appl Ecol 15: 590-598. https://doi.org/10.1016/j.baae.2014.08.007

Bassiri M, Wilson AM, Grami B (1988) Root excision and dehydration effects on water uptake in four range species. J Range Manag 41:378-383. https://doi.org/10.2307/3899570

Bell DL, Sultan SE (1999) Dynamic phenotypic plasticity for root growth in Polygonum: a comparative study. Am J Bot 86: 807-819. https://doi.org/10.2307/2656702

Bi A, Fan J, Hu Z, Wang G, Amombo E, Fu J, Hu T (2016) Differential acclimation of enzymatic antioxidant metabolism and photosystem ii photochemistry in tall fescue under drought and heat and the combined stresses. Front Plant Sci 7:453. https://doi.org/10.3389/fpls.2016.00453

Bongers FJ, Olmo M, Lopez-Iglesias B, Anten NPR, Villar R (2017) Drought responses, phenotypic plasticity and survival of Mediterranean species in two different microclimatic sites. Plant Biol 19:386-395

Boyer JS (1982) Plant productivity and environment. Science 218: 443-448. https://doi.org/10.1126/science.218.4571.443

Briske DD, Wilson AM (1978) Moisture and temperature requirements for adventitious root development in blue grama seedlings. J Range Manag 31:174-178. https://doi.org/10.2307 /3897173

Bristiel P, Roumet C, Violle C, Volaire F (2019) Coping with drought: root trait variability within the perennial grass Dactylis glomerata captures a trade-off between dehydration avoidance and dehydration tolerance. Plant Soil 434:327342. https://doi.org/10.1007/s11104-018-3854-8

Chapin FS III, Autumn K, Pugnaire F (1993) Evolution of suites of traits in response to environmental stress. Am Nat 142:S78S92 https://www.jstor.org/stable/2462710

Comas LH, Becker SR, Cruz VMV, Byrne PF, Dierig DA (2013) Root traits contributing to plant productivity under drought. Front Plant Sci 4:442. https://doi.org/10.3389 /fpls.2013.00442

Cornelissen JHC, Lavorel S, Garnier E, Díaz S, Buchmann N, Gurvich DE, Reich PB, ter Steege H, Morgan HD, van der Heijden MGA, Pausas JG, Poorter H (2003) A handbook of protocols for standardised and easy measurement of plant functional traits worldwide. Aust J Bot 51:335-380. https://doi.org/10.1071/BT02124

Couso LL, Fernández RJ (2012) Phenotypic plasticity as an index of drought tolerance in three Patagonian steppe grasses. Ann Bot 110:849-857. https://doi.org/10.1093/aob/mcs147

Davies W, Bacon M (2003) Adaptation of roots to drought. Root Ecology, Ecol Stud 168:173-192. https://doi.org/10.1007 /978-3-662-09784-7 7

Eziz A, Yan Z, Tian D, Han W, Tang Z, Fang J (2017) Drought effect on plant biomass allocation: a meta-analysis. Ecol Evol 7:11002-11010. https://doi.org/10.1002/ece3.3630

Falster DS, Warton DI, Wright IJ (2006) SMATR: standardised major axis tests and routines, ver 2.0. http://www.bio.mq.edu. au/ecology/SMATR/

Fitter A (2002) Characteristics and functions of root systems. Plant Roots: The Hidden Half, Third Edition, (eds Y. Waisel, A. Eshel, T. Beeckman \& U. Kafkafi), pp 21-50. CRC Press

Forde BG (2009) Is it good noise? The role of developmental instability in the shaping of a root system. J Exp Bot 60 : 3989-4002. https://doi.org/10.1093/jxb/erp265

Fort F, Jouany C, Cruz P (2013) Root and leaf functional trait relations in Poaceae species: implications of differing resource acquisition strategies. J Plant Ecol 6:211-219. https://doi.org/10.1093/jpe/rts034

Freschet GT, Violle C, Bourget MY, Scherer-Lorenzen M, Fort F (2018) Allocation, morphology, physiology, architecture: the multiple facets of plant above- and below-ground responses to resource stress. New Phytol 219:1338-1352. https://doi. org/10.1111/nph.15225

Funk JL, Larson JE, Ames G, Butterfield B, Cavender-Bares J, Firn J, Laughlin DC, Sutton-Grier A, Williams L, Wright J (2017) Revisiting the holy grail: using plant functional traits to understand ecological processes. Biol Rev 92:1156-1173. https://doi.org/10.1111/brv.12275

Gaviria J, Engelbrecht BMJ (2015) Effects of drought, pest pressure and light availability on seedling establishment and growth: their role for distribution of tree species across a 
tropical rainfall gradient. PLoS One 10:e143955. https://doi. org/10.1371/journal.pone.0143955

Gill RA, Jackson RB (2000) Global patterns of root turnover for terrestrial ecosystems. New Phytol 147:13-31. https://doi. org/10.1046/j.1469-8137.2000.00681.x

Glimskär A (2000) Estimates of root system topology of five plant species grown at steady-state nutrition. Plant Soil 227:249256. https://doi.org/10.1023/A:1026531200864

Gonzalez-Dugo V, Durand JL, Gastal F, Bariac T, Poincheval J, Bardou G, Biron P, Cousson L, Eprinchard A, Millet G, Richard P, Terrasson J-P (2012) Restricted root-to-shoot translocation and decreased sink size are responsible for limited nitrogen uptake in three grass species under water deficit. Environ Exp Bot 75:258-267. https://doi.org/10.1016 /j.envexpbot.2011.07.009

Granier C, Aguirrezabal L, Chenu K, Cookson SJ, Dauzat M, Hamard P, Thioux JJ, Rolland G, Bouchier-Combaud S, Lebaudy A, Muller B, Simonneau T, Tardieu F (2006) PHENOPSIS, an automated platform for reproducible phenotyping of plant responses to soil water deficit in Arabidopsis thaliana permitted the identification of an accession with low sensitivity to soil water deficit. New Phytol 169:623-635. https://doi.org/10.1111/j.14698137.2005.01609.x

Harada J, Yamazaki K (1993) Roots. Science of the Rice Plant, Volume 1, Morphology. (eds T. Matsuo, K. Hoshikawa), pp 133-186. Food and Agriculture Policy Research Centre, Tokyo

Hodge A (2004) The plastic plant: root responses to heterogeneous supplies of nutrients. New Phytol 162:9-24. https://doi. org/10.1111/j.1469-8137.2004.01015.x

Hodge A, Berta G, Doussan C, Merchan F, Crespi M (2009) Plant root growth, architecture and function. Plant Soil 321:153187. https://doi.org/10.1007/s11104-009-9929-9

Hoekstra NJ, Finn JA, Hofer D, Lüscher A (2014) The effect of drought and interspecific interactions on depth of water uptake in deep- and shallow-rooting grassland species as determined by $\delta^{18} \mathrm{O}$ natural abundance. Biogeosciences 11:44934506. https://doi.org/10.5194/bg-11-4493-2014

Huang B, DaCosta M, Jiang Y (2014) Research advances in mechanisms of turfgrass tolerance to abiotic stresses:from physiology to molecular biology. Crit Rev Plant Sci 33: 141-189. https://doi.org/10.1080/07352689.2014.870411

James JJ, Rinella MJ, Svejcar T (2012) Grass seedling demography and sagebrush steppe restoration. Rangel Ecol Manag 65:409-417. https://doi.org/10.2111/REM-D-11-00138.1

Johnson DA, Asay KH (1993) Viewpoint: selection for improved drought response in cool-season grasses. J Range Manag 46: 194-202. https://doi.org/10.2307/4002606

Jupp AP, Newman EI (1987) Morphological and anatomical effects of severe drought on the roots of Lolium perenne $\mathrm{L}$. New Phytol 105:393-402. https://doi.org/10.1111/j.14698137.1987.tb00876.x

Kellermeier F, Chardon F, Amtmann A (2013) Natural variation of Arabidopsis root architecture reveals complementing adaptive strategies to potassium starvation. Plant Physiol 161: 1421-1432. https://doi.org/10.1104/pp.112.211144

Khasanova A, James JJ, Drenovsky RE (2013) Impacts of drought on plant water relations and nitrogen nutrition in dryland perennial grasses. Plant Soil 372:541-552. https://doi. org/10.1007/s11104-013-1747-4
Kitajima K, Myers JA (2008) Seedling ecophysiology:strategies toward achievement of positive net carbon balance. Seedling Ecology and Evolution (eds M.A. Leck, T. Parker \& R.L. Simpson), pp. 172-188. Cambridge University Press. https://doi.org/10.1017/CBO9780511815133.010

Kong D, Wu H, Wang M, Simmons M, Lü X, Yu Q, Han X (2010) Structural and chemical differences between shoot- and rootderived roots of three perennial grasses in a typical steppe in Inner Mongolia China. Plant Soil 336:209-217. https://doi. org/10.1007/s11104-010-0467-2

Larson JE, Funk JL (2016) Seedling root responses to soil moisture and the identification of a belowground trait spectrum across three growth forms. New Phytol 210:827-838. https://doi.org/10.1111/nph.13829

León MF, Squeo FA, Gutiérrez JR, Holmgren M (2011) Rapid root extension during water pulses enhances establishment of shrub seedlings in the Atacama Desert. J Veg Sci 22:120 129. https://doi.org/10.1111/j.1654-1103.2010.01224.x

Liu ZM, Thompson K, Spencer R, Reader RJ (2000) A comparative study of morphological responses of seedling roots to drying soil in 20 species from different habitats. Acta Bot Sin 42:628-635

Lloret F, Peñuelas J, Estiarte M (2005) Effects of vegetation canopy and climate on seedling establishment in Mediterranean shrubland. J Veg Sci 16:67-76. https://doi. org/10.1111/j.1654-1103.2005.tb02339.x

Lobet G, Couvreur V, Meunier F, Javaux M, Draye X (2014) Plant water uptake in drying soils. Plant Physiol 164:1619-1627. https://doi.org/10.1104/pp.113.233486

Ludlow MM (1989) Strategies of response to water stress. In: Kreeb KH, Richter H, Hinckley TM (eds) Structural and functional responses to environmental stresses: water shortage. SPB Academic Publishing BV, The Hague, pp 269-281

Malamy JE (2005) Intrinsic and environmental response pathways that regulate root svstem architecture. Plant Cell Environ 28: 67-77. https://doi.org/10.1111/j.1365-3040.2005.01306.x

Moles AT, Leishman MR (2008) The seedling as part of a plant's life history strategy. In: Leck MA, Parker VT, Simpson RL (eds) Seedling ecology and evolution. Cambridge University Press, Cambridge, pp 217-238

Moles AT, Westoby M (2004) What do seedlings die from and what are the implications for evolution of seed size? Oikos 106:193-199. https://doi.org/10.1111/j.00301299.2004.13101.x

Nicotra AB, Babicka N, Westoby M (2002) Seedling root anatomy and morphology: an examination of ecological differentiation with rainfall using phylogenetically independent contrasts. Oecol 130:136-145. https://doi.org/10.1007/s004420100788

Padilla FM, Pugnaire FI (2007) Rooting depth and soil moisture control Mediterranean woody seedling survival during drought. Funct Ecol 21:489-495. https://doi.org/10.1111 /j.1365-2435.2007.01267.x

Padilla FM, Miranda JD, Jorquera MJ, Pugnaire FI (2009) Variability in amount and frequency of water supply affects roots but not growth of arid shrubs. Plant Ecol 204:261-270. https://doi.org/10.1007/s11258-009-9589-0

Padilla FM, Aarts BHJ, Roijendijk YOA, de Caluwe H, Mommer L, Visser EJW, de Kroon H (2013) Root plasticity maintains growth of temperate grassland species under pulsed water supply. Plant Soil 369:377-386. https://doi.org/10.1007 /s11104-012-1584-x 
Paula S, Pausas JG (2011) Root traits explain different foraging strategies between resprouting life histories. Oecol 165:321331. https://doi.org/10.1007/s00442-010-1806-y

Pigliucci M (1998) Developmental phenotypic plasticity: where internal programming meets the external environment. Curr Opin Plant Biol 1998:87-91. https://doi.org/10.1016/S13695266(98)80133-7

Poorter H, Bühler J, van Dusschoten D, Climent J, Postma JA (2012) Pot size matters: a meta-analysis of the effects of rooting volume on plant growth. Funct Plant Biol 39:839850

R Core Team (2014) R: A language and environment for statistical computing. R Foundation for Statistical Computing, Vienna, Austria. URL http:/www.R-project.org/

Raiche G, Magis D (2015) nFactors: parallel analysis and non graphical solutions to the Cattell scree test. $\mathrm{R}$ package Version 2.3.3

Ramírez-Valiente J-A, Aranda I, Sanchéz-Gómez D, RodríguezCalcerrada J, Valladares F, Robson TM (2019) Increased root investment can explain the higher survival of seedlings of 'Mesic' Quercus suber than 'xeric' Quercus ilex in sandy soils during a summer drought. Tree Physiol 39:64-75. https://doi.org/10.1093/treephys/tpy084

Reader RJ, Jalili A, Grime JP, Spencer RE, Matthews N (1993) A comparative study of plasticity in seedling rooting depth in drying soil. J Ecol 81:543-550. https://doi.org/10.2307 12261532

Reich PB (2014) The world-wide'fast-slow'plant economics spectrum:a traits manifesto. J Ecol 102:275-301. https://doi. org/10.1111/1365-2745.12211

Rosas U, Cibrian-Jaramillo A, Ristova D, Banta JA, Gifford ML, Fan AH, Zhou RW, Kim GJ, Krouk G, Birnbaum KD, Purugganan MD, Coruzzi GM (2013) Integration of responses within and across Arabidopsis natural accessions uncovers loci controlling root systems architecture. P Natl Acad Sci USA 110:15133-15138. https://doi.org/10.1073 /pnas. 1305883110

Rostamza M, Richards RA, Watt M (2013) Response of millet and sorghum to a varying water supply around the primary and nodal roots. Ann Bot 112:439-446. https://doi.org/10.1093 /aob/mct099

Ryser P (1996) The importance of tissue density for growth and life span of leaves and roots: a comparison of five ecologically contrasting grasses. Funct Ecol 10:717-723. https://doi. org/10.2307/2390506

Saidi A, Ookawa T, Hirasawa T (2010) Responses of root growth to moderate soil water deficit in wheat seedlings. Plant Prod Sci 13:261-268. https://doi.org/10.1626/pps.13.261
Sun J, Meyer W, Cross J, Huang B (2013) Growth and physiological traits of canopy and root systems associated with drought resistance in tall fescue. Crop Sci 53:575-584. https://doi. org/10.2135/cropsci2012.05.0292

Tardieu F (2012) Any trait or trait-related allele can confer drought tolerance: just design the right drought scenario. J Exp Bot 63:25-31. https://doi.org/10.1093/jxb/err269

Valladares F, Sanchez-Gomez D, Zavala MA (2006) Quantitative estimation of phenotypic plasticity: bridging the gap between the evolutionary concept and its ecological applications. J Ecol 94:1103-1116. https://doi.org/10.1111/j.13652745.2006.01176.x

Valladares F, Gianoli E, Gómez JM (2007) Ecological limits to plant phenotypic plasticity. New Phytol 176:749-763. https://doi.org/10.1111/j.1469-8137.2007.02275.x

Volaire F (2018) A unified framework of plant adaptive strategies to drought: crossing scales and disciplines. Glob Chang Biol 24:2929-2938

Volaire F, Barkaoui K, Norton M (2014) Designing resilient and sustainable grasslands for a drier future: adaptive strategies, functional traits and biotic interactions. Eur J Agron 52:8189. https://doi.org/10.1016/j.eja.2013.10.002

Warton DI, Wright IJ, Falster DS, Westoby M (2006) Bivariate line-fitting methods for allometry. Biol Rev 81:259-291. https://doi.org/10.1017/S1464793106007007

Weemstra M, Mommer L, Visser EJW, van Ruijven J, Kuyper TW, Mohren GMJ, Sterck FJ (2016) Towards a multidimensional root trait framework: a tree root review. New Phytol 211: 1159-1169. https://doi.org/10.1111/nph.14003

Wilson AM, Briske DD (1979) Seminal and adventitious root growth of blue grama seedlings on the central plains. J Range Manag 32:209-213. https://doi.org/10.2307/3897124

Wilson AM, Hyder DN, Briske DD (1976) Drought resistance characteristics of blue grama seedlings. Agron J 68:479-484. https://doi.org/10.2134/agronj1976.00021962006800030012x

Yang H-L, Zhu X-W, Dong M, Huang Z-Y, Cao Z-P (2005) Responses of caryopsis germination, seedling emergence, and development to sand water content of Agropyron cristatum (L.) Gaertn. And Bromus inermis Leyss. J Integr Plant Biol 47:1450-1458. https://doi.org/10.1111/j.17447909.2005.00170.x

Živčák M, Brestič M, Olšovská K, Slamka P (2008) Performance index as a sensitive indicator of water stress in Triticum aestivum L. Plant Soil Environ 54:133-139

Publisher's note Springer Nature remains neutral with regard to jurisdictional claims in published maps and institutional affiliations. 